\title{
REPRESENTATIVITY OF QUATERNARY MAMMALS FROM THE SOUTHERN BRAZILIAN CONTINENTAL SHELF
}

\author{
ALEX SANDRO SCHILLER AIRES \\ Programa de Pós-Graduação em Ciências Biológicas, Laboratório de Paleobiologia, Universidade Federal do Pampa, \\ Campus São Gabriel, Av. Antônio Trilha, 1847, 93700-000, São Gabriel, RS, Brazil.asschillera@gmail.com \\ RENATO PEREIRA LOPES \\ Setor de Paleontologia, Instituto de Oceanografia, FURG, Campus Carreiros, 96201-900, Rio Grande, RS, Brazil. \\ paleonto_furg@yahoo.com.br
}

\begin{abstract}
Fossils of terrestrial mammals from the southern Brazilian continental shelf have been known since the late 19th century. The fossils are relatively common and represent several taxonomic groups of the Pleistocene megafauna. Although the systematics of the fossil assemblage is well known, the relative proportions among taxonomic groups and their skeletal elements have not been evaluated yet. Here are presented the results of a survey of the diversity of skeletal elements and taxa among 2,391 specimens belonging to the paleontological collection of the Universidade Federal do Rio Grande (FURG). The survey revealed that the most common taxa are the artiodactyls, ground sloths, glyptodontids and toxodontids, while carnivores, rodents and litopterns are very scarce. The most abundant skeletal elements are osteoderms of cingulates (mostly glyptodontids) and teeth of other groups. Although paleoecological and paleoenvironmental inferences are very hard to obtain because the fossils do not have a stratigraphic setting, encompass a wide time span, of some $700 \mathrm{ky} \mathrm{BP,} \mathrm{and}$ represent several environments and climates, some patterns of taxonomic abundance are apparently related to ecological factors, while others seem to result from taphonomic processess.
\end{abstract}

Key words: megafauna, Pleistocene, Southern Brazil, continental shelf.

RESUMO - Fósseis de mamíferos terrestres procedentes da plataforma continental do sul do Brasil são conhecidos desde o século 19. Esses fósseis são relativamente comuns e representam diversos grupos taxonômicos da megafauna do Pleistoceno. Embora a sistemática da assembleia fóssil seja bem conhecida, as proporções relativas entre os diferentes grupos e seus elementos esqueletais ainda não foram avaliadas. Aqui são apresentados os resultados de um levantamento da diversidade de elementos esqueletais e táxons entre 2.391 espécimes pertencentes à coleção paleontológica da Universidade Federal do Rio Grande (FURG). O levantamento revelou que os táxons mais comuns são artiodáctilos, preguiças terrícolas, gliptodontídeos e toxodontídeos, enquanto carnívoros, roedores e litopternos são bastante escassos. Os elementos esqueletais mais abundantes são osteodermos de cingulados com predominância de gliptodontídeos, e dentes de outros grupos. Embora seja difícil fazer inferências paleoecológicas e paleoambientais, devido ao fato de os fósseis não apresentarem contexto estratigráfico, representarem grande intervalo temporal da ordem de $700 \mathrm{ky} \mathrm{BP}$ e indicarem diferentes tipos de ambientes e climas, alguns padrões de abundância taxonômica parecem relacionados a fatores ecológicos, enquanto outros parecem ser resultados de processos tafonômicos.

Palavras-chave: megafauna, Pleistoceno, sul do Brasil, plataforma continental.

\section{INTRODUCTION}

Fossils of terrestrial mammals have been collected from continental shelves all around the globe, such as the northeastern coast of North America (Whitmore et al., 1967) and the North Sea (Van Kolfschoten \& Laban, 1995; Mol et al., 2006). Similar fossils have also been found on the Argentinean continental shelf, in front of the estuary of the La Plata River (Cione et al., 2005) and the coast of Buenos Aires Province (Tonni \& Cione, 1999), and on the northeastern Uruguayan coast (Rinderknecht, 2006). In Brazil, fossils of terrestrial mammals preserved on the continental shelf have been recorded from the coast of Rio Grande do Sul State since the late 19th century, when German naturalist Hermann Von Ihering described in a letter to Argentinean naturalist Florentino Ameghino the presence of some osteoderms of glyptodonts on the beach (Ameghino, 1891). Recently, the presence of such remains in deeper areas of the shelf, collected by fishermen, has also been published (Lopes \& Buchmann, 2010). The studies on such fossils have been aimed mostly at their taxonomic identification (e.g. Cunha, 1959; Paula Couto \& Cunha, 1965; Oliveira, 1992, 1996; Rodrigues \& Ferigolo, 2004; Rodrigues et al., 2004; Scherer, 2005; Marcon, 2007; Scherer et al., 2009). Other studies have focused on the distribution of such remains 
along the coast (Buchmann, 1994), their taphonomy (Lopes et al., 2008) and ages (Lopes et al., 2010).

The fossils are found disarticulated, exhibiting signs of post mortem breakage and abrasion (Lopes et al., 2008). They come from large concentrations of marine and terrestrial skeletal remains on the inner continental shelf, at depths between 0 and 20 m (Figueiredo, 1975; Buchmann, 2002). During autumn and winter, storm waves erode these concentrations and transport the fossils to the beach, where they are collected. Besides terrestrial mammals, the concentrations also contain remains of marine mollusks (Lopes \& Buchmann, 2008), corals, echinoderms, crustaceans (Buchmann, 1994; Lopes, 2011), teleost (Richter, 1987) and elasmobranch fishes (Buchmann \& Rincón Filho, 1997), pinnipeds (Oliveira \& Drehmer, 1997), cetaceans (Cunha, 1982; Ribeiro et al., 1998), seabirds (Lopes et al., 2006) and reptiles (Hsiou \& Fortier, 2007; Hsiou, 2009).

The presence of terrestrial fossil mammals in a modern marine environment is attributed to the existence of Pleistocene continental fossiliferous deposits that were reworked by sealevel oscillations. During the Quaternary glacial maxima, the ocean levels reached some $130 \mathrm{~m}$ below present-day levels, thus exposing large areas of the continental shelves all around the world that were occupied by terrestrial environments and were covered and reworked by sea level rises at the end of glaciations (Lopes \& Buchmann, 2010). Recent ages obtained by Electron Spin Resonance (ESR) on seven fossil teeth from the southern Brazilian continental shelf revealed that the fossils are between $650 \pm 100$ and $18 \pm 3 \mathrm{ky} \mathrm{BP}$, and represent several temporally distinct fossil assemblages (Lopes et al., 2010). The large age span, the co-occurrence of fossils that indicate arid and open environments such as Reithrodon Waterhouse, 1837 and Dolichotinae rodents, and other records (Cunha, 1959; Rodrigues \& Ferigolo, 2004) such as Tapirus Brunnich, 1772, Hydrochoerus Brisson, 1762 and Myocastor Kerr, 1792 that indicate permanently humid or forested environments, plus the lack of a precise stratigraphic context, difficult paleocommunity reconstructions based on fossils from the continental shelf.

Although the fossils are somewhat common and several mammalian groups are recognized from these deposits (Table 1), until now there has been no detailed survey regarding the relative proportions among taxa, given that the available taxonomic studies are based on specific groups and isolated specimens. Here is presented a survey of the relative proportions of mammalian taxa and respective skeletal elements found on the southern Brazilian continental shelf. The present survey is aimed at improving the knowledge regarding such taxa and evaluating patterns that may have influenced taxonomic and anatomic representativity. Although representing distinct assemblages with different ages, mixed together by erosive processes related to sea-level oscillations, for the purposes of the present study all fossils are considered as a single assemblage.

\section{GEOLOGICAL SETTING}

The Coastal Plain of Rio Grande do Sul State (CPRS) was formed after the split between South America and Africa in the

Table 1. Fossils of terrestrial mammals from the deposits of the southern Brazilian continental shelf (classification according to McKenna \& Bell, 1997).

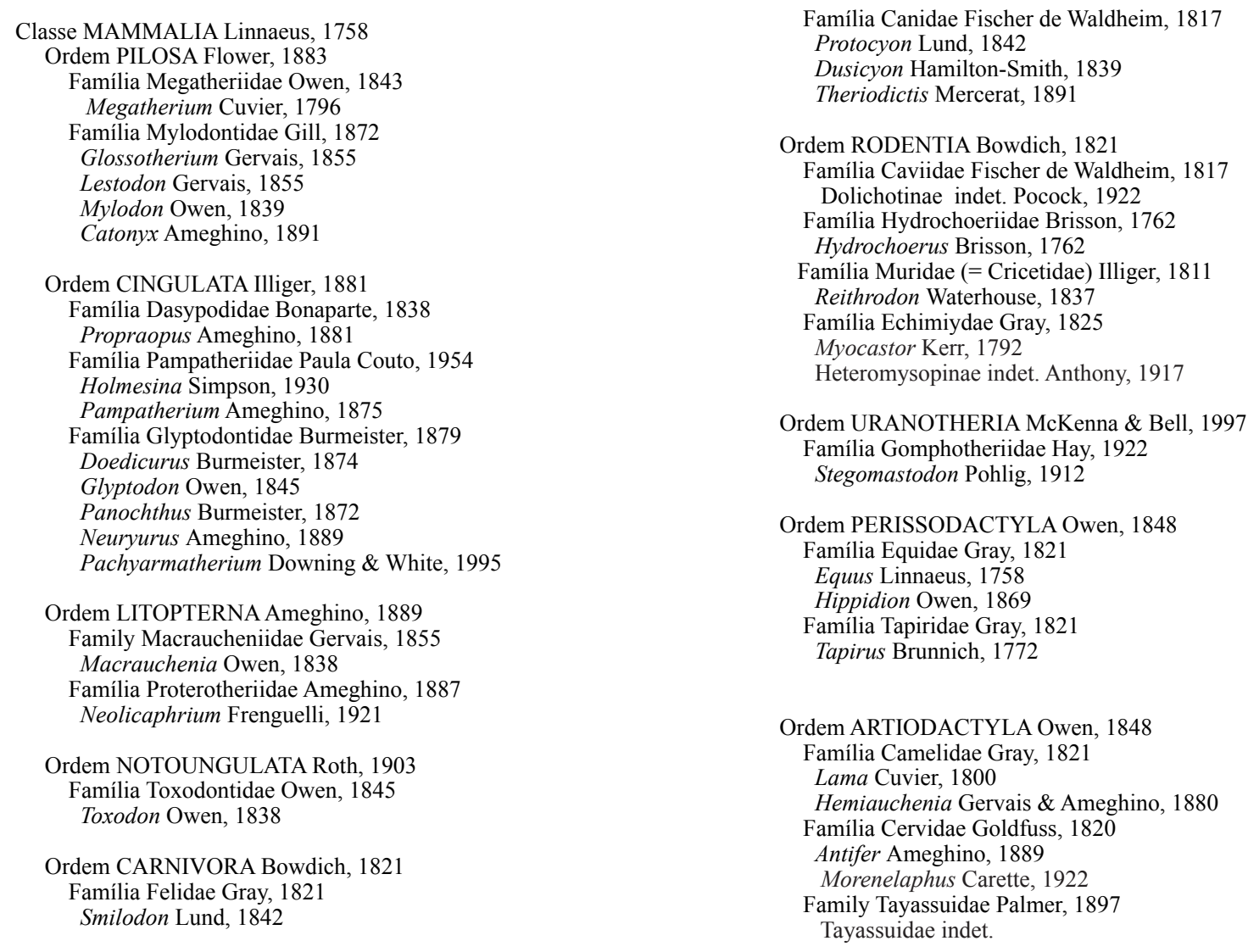


Late Cretaceous, by accumulation of sediments eroded from the older, higher geomorphologic units (Figure 1). Between the Neogene and Quaternary the morphology of the CPRS was affected by glacioeustatic oscillations, which led to the formation of two major depositional systems: the Alluvial Fans System and the Pleistocene-Holocene Complex Multiple Barrier (Villwock \& Tomazelli, 1995).

The latter unit is subdivided into four large barrier-lagoon depositional systems and associated features. Each barrierlagoon was formed by a marine transgression, correlated to late Pleistocene-Holocene interglacial episodes (Tomazelli et al., 2000). The constituent sediments are essentially siliciclastic,
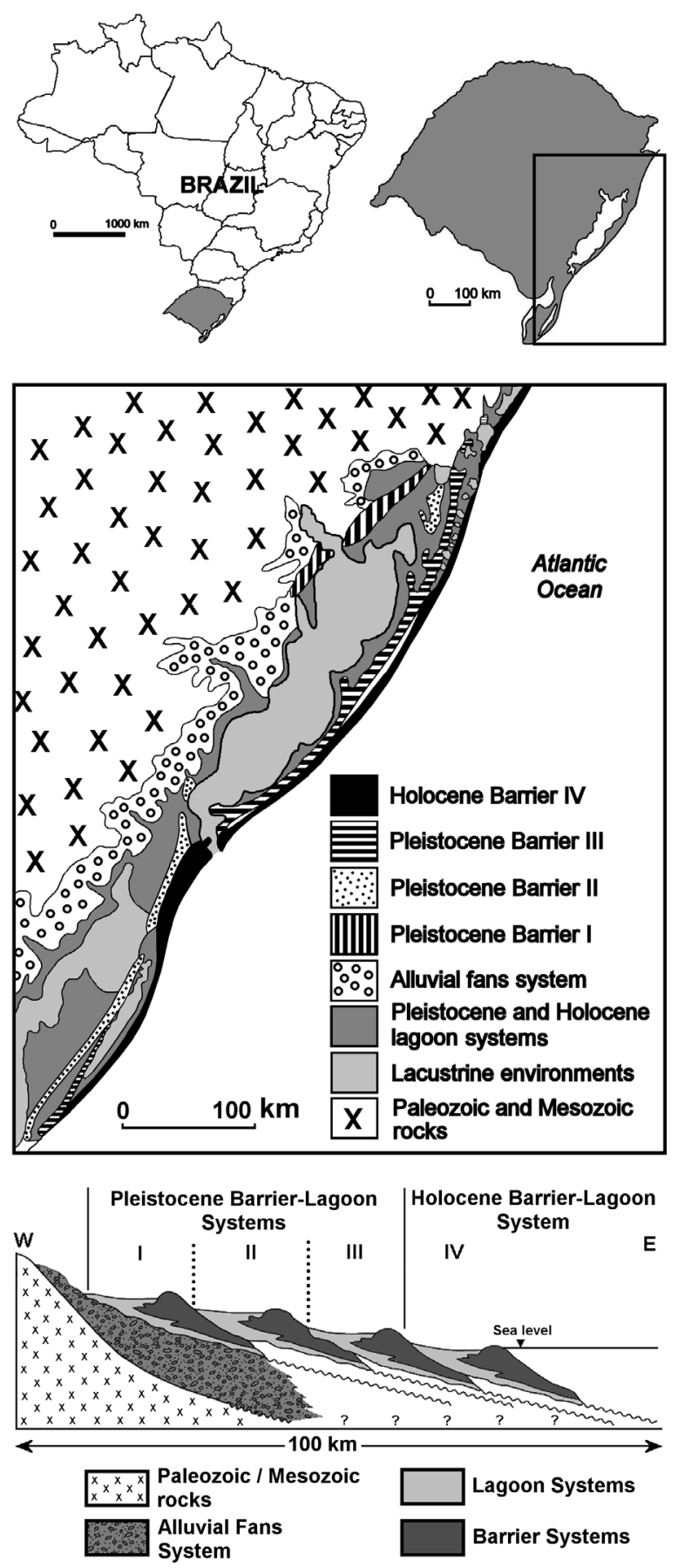

Figure 1. Location of Rio Grande do Sul State and simplified structure of the coastal plain (modified from Tomazelli et al., 2000). well-sorted and mature sands, with small amounts of organic matter, biogenic carbonate, diagenetic clays and concentrations of heavy minerals (Villwock \& Tomazelli, 1995).

The continental shelf, which constitutes the submerged portion of the CPRS, has a low slope (average ratio of 1:1.000) and the shelf break is located at depths between 80 and 120 meters. The middle-central portion of the shelf is wide, morphologically reworked and presents paleofluvial channels and sand banks (Corrêa et al., 1996). During the Holocene transgression of 6-7 ky BP, variations in the rates of sea-level rise promoted the reworking and concentration of clastic terrigenous sediments and formed abrasion terraces on the shelf (Kowsmann \& Costa, 1974; Martins et al., 1996). The deposits of the shelf containing terrestrial remains were formed during sea-level regressions, when large portions of the then exposed shelf were occupied by terrestrial ecosystems (Lopes et al., 2010; Lopes \& Buchmann, 2010).

\section{MATERIAL AND METHODS}

Systematic collecting of fossils along the beaches of Rio Grande do Sul State has been performed in the last 15 years by researchers from the Universidade Federal do Rio Grande (FURG). The collection sites are concentrated in the southern portion of the coast, between the estuary of Patos Lagoon and Chuí Creek. During these activities, $1 \mathrm{~km}$-long sections of the coast, between the surf zone and frontal dunes, are surveyed for fossils and geological samples. The remains are found disarticulated and exhibit signs of abrasion by transport; most fossils are incomplete, and compact-shaped elements such as osteoderms, astragali and phalanges are generally the best preserved (Lopes et al., 2008). The occurrence of fossils along the coast is not uniform (Buchmann, 1994). The largest concentration of mammalian remains is found in a $\sim 40 \mathrm{~km}$-long sector where large and thick konzentrat-lagerstätte of fossil marine shells, called "concheiros" (Figure 2) are formed on the beach by redeposition of bioclasts transported from the continental shelf by storm waves (Figueiredo Jr., 1975).

The studied specimens, a total of 2,391 fossils, are deposited in the paleontological collection of FURG. Each specimen was identified to the lowest taxonomic category where possible, and classified as cranial elements (skulls, mandibles, antlers), isolated teeth, axial elements (vertebrae and ribs), appendicular elements (scapulae and long bones), podials (carpals, metacarpals, tarsals, metatarsals and phalanges) and accessory elements (osteoderms, caudal tubes).

Abbreviations. CPRS, coastal plain of Rio Grande do Sul State; FURG, Universidade Federal do Rio Grande; LGP, Laboratório de Geologia e Paleontologia; LGP-E, Toxodontidae; LGP-F, Litopterna; LGP-G, Gomphotheriidae; LGP-I, Artiodactyla; LGP-K, Perissodactyla; LGP-N, Dasypodidae; LGP-P, Glyptodontidae; LGP-PC, continental shelf; LGP-Q, Mylodontidae.

\section{RESULTS}

The most abundant skeletal elements are osteoderms of cingulates, followed by teeth (Figure 3 ). The most common cranial elements are incomplete cervid antlers and fragments of the occipital portion of skulls; the most complete skull is almost unrecognizable, but seems to be of a ground sloth 


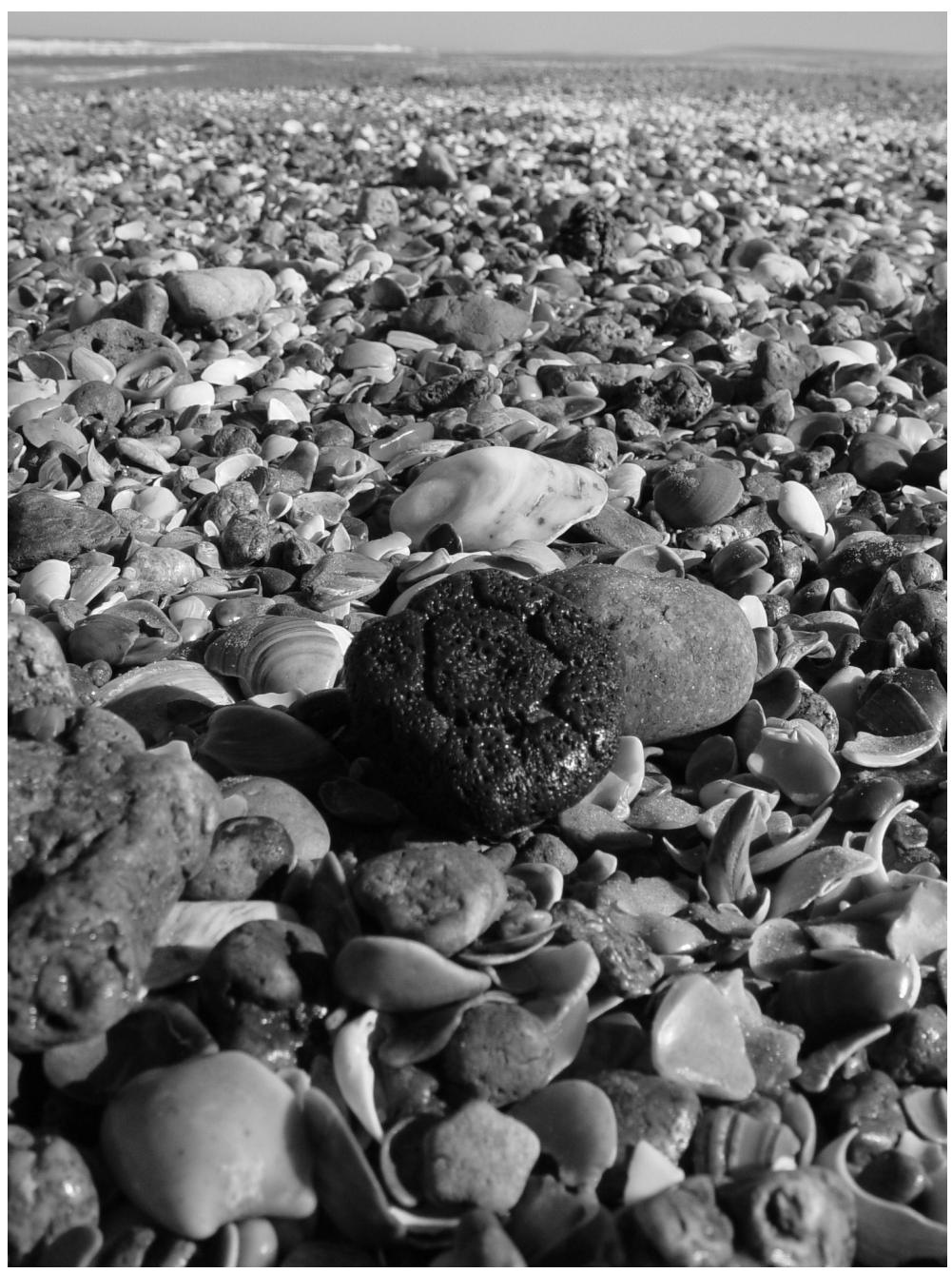

Figure 2. Osteoderm of Glyptodon associated with marine fossil remains in the "concheiros", CPRS, southernmost Brazil. Not in scale $1 / 1$.

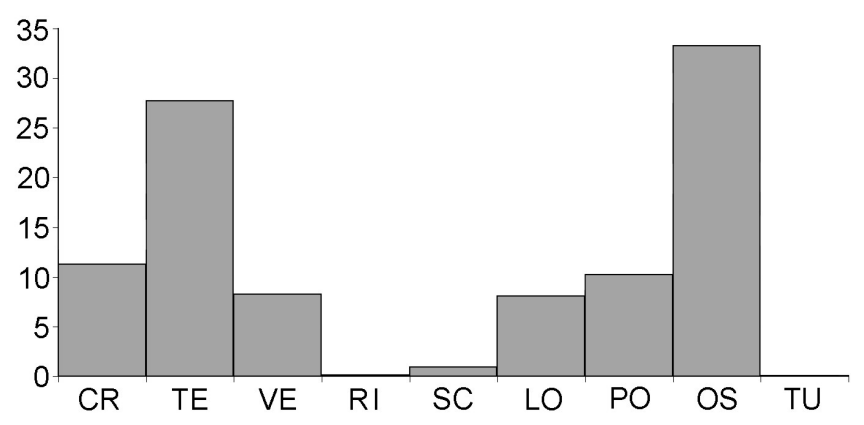

Figure 3. Relative percentages among the identified skeletal remains. Abbreviations: CR, cranial elements; TE, teeth; VE, vertebrae; RI, ribs; SC, scapulae; LO, long bones; PO, podials; OS, osteoderms; TU, caudal tubes.

because of the internal pneumatization (Figure 4A). The most common podial elements are astragali (Figures $4 \mathrm{~B}, \mathrm{C}$ ), followed by phalanges and carpals/tarsals (Figure 4D). Long bones are represented essentially by incomplete specimens (Figures 4E-G). Vertebrae include complete specimens, but most are incomplete or fragments represented by centra without neural arches and isolated neural spines, difficult to assign to any specific taxon. Scapulae and ribs are all incomplete specimens.

Of the total analyzed specimens, 214 could not be taxonomically identified due to reworking by marine dynamics, which destroys most of the diagnostic characters by abrasion and/or fragmentation (Lopes et al., 2008). These include 121 vertebrae, 33 podials, 26 long bones, 22 scapulae, 9 skulls and 3 ribs. The remaining 2,177 elements could be assigned to several taxonomic groups (Figure 5), but not all known taxa from the continental shelf are represented, among them the rodents and canids. The most common taxa are artiodactyls, represented mostly by antler fragments, podials and teeth. Among the antlers, 145 could be identified, being 28 of Antifer Ameghino, 1,889 and 117 of Morenelaphus Carette, 1922; the remaining 167 could not be assigned to any specific genus due to abrasion and fragmentation. Podials and teeth of this group are very common and well preserved; however, a detailed revision is needed in order to distinguish between cervids and camelids. The medium-sized taxa (those with body mass between 10 and $100 \mathrm{~kg}$, according to estimates by Fariña et al., 1998), represented by cervids, are the most common, followed by largesized ones (body masses between 100 and more than $1000 \mathrm{~kg}$ ), such as glyptodontids, ground sloths, toxodontids, litopterns, proboscideans and carnivores. Although Fariña et al. (1998) and Cione et al. (2003) did not provide estimates of body mass for pampatheriids and proterotheriids, these can be considered medium-sized taxa.

Cingulate xenarthrans are very common, with glyptodontids as the most conspicuous group, followed by pampatheriids and 

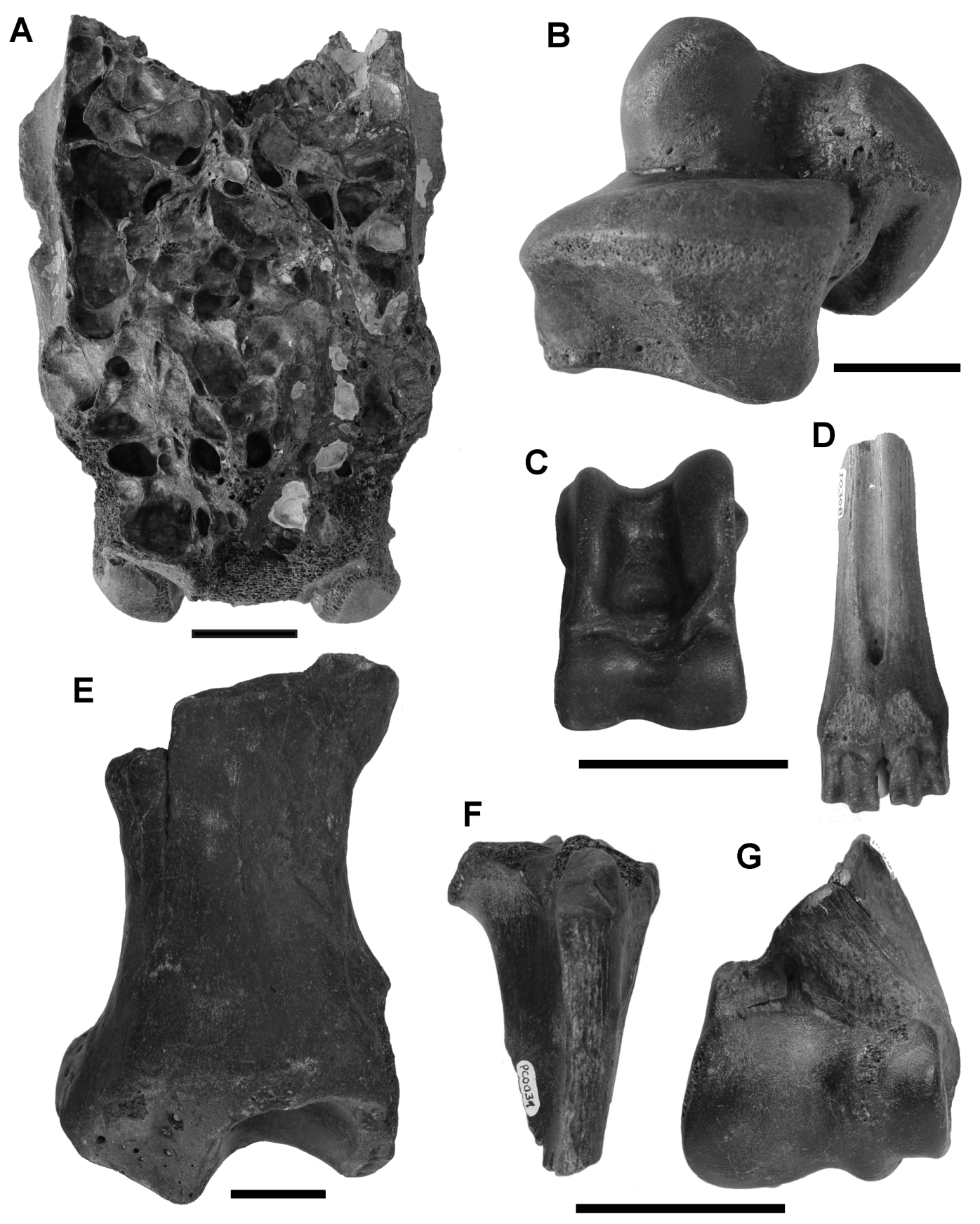

Figure 4. Fossils of terrestrial mammals. A, LGP-PC0045, unidentified skull, probably a ground sloth (in dorsal view); B, LGP-Q0013, right astragalus of Lestodon sp.; C, LGP-I0017, astragalus of an artiodactyl; D, LGP-I0308, metatarsal of an artiodactyl; E, LGP-Q0016, tibia of Lestodon sp.; F, LGP-PC0031, unidentified proximal end of a tibia; G, LGP-PC0205, unidentified distal end of a humerus. Scale bars $=50 \mathrm{~mm}$.

dasypodids (Figure 6). Glyptodontids are easily diagnosed by the external morphology of the carapace osteoderms. The identified genera include Glyptodon Owen, 1845 (501 specimens), Panochthus Burmeister, 1872 (44), Doedicurus Burmeister, 1874 (23) and Neuryurus Ameghino, 1889 (8). Identification of the latter, which have osteoderms with irregular surface and without distinct textures (Zurita et al., 2006) is sometimes dubious, because abrasion can obliterate the fine-scale textures on osteoderms of Panochthus making them look like Neuryurus. Some specimens of Glyptodon and Panochthus are represented by two or more fused osteoderms. Besides osteoderms, the only identified glyptodontid remains are two teeth fragments and incomplete caudal tubes attributed to Panochthus. Pampatheriids are represented by 116 osteoderms of Pampatherium Ameghino, 1875 and 53 of Holmesina Simpson, 1930. The most numerous are the elongated, subrectangular osteoderms of the mobile belt, although elements from the cephalic shield and pelvic and pectoral bucklers are common. The genus Pachyarmatherium Downing \& White, 1995 is represented by only three osteoderms. This taxon was only recently described from fossiliferous deposits of the continental shelf (Bostelmann et al., 2008; Ribeiro, 2008) and also from Pleistocene deposits in northeastern Brazil (Porpino et al., 2009). Dasypodid fossils are very scarce, consisting of only seven osteoderms attributed to Propraopus 
Ameghino, 1881, plus three others that could not be identified.

Remains of pilose xenarthrans include members of the Mylodontidae (131 specimens) and Megatheriidae (44). Mylodontid sloths are represented by Glossotherium Gervais, 1855 (22 specimens), Lestodon Gervais, 1855 (14), Mylodon Owen, 1839 (11) and Catonyx Ameghino, 1891 (5), as well as 83 unidentified specimens. The most conspicuous fossils of this group are isolated teeth, which are difficult to identify because of the similar morphology of the first molariform teeth. In Catonyx, the teeth have a subtriangular transverse profile distinct from those of the mylodontines. Other features that allowed distinguishing between some genera are the morphology of the distal portion of the tibia and the astragalus (Kraglievich, 1934). The megatheriid sloths were identified by teeth (38 specimens) and one ungual phalange. Although Megatherium Cuvier, 1796 is the only megatheriid cited for the deposits of the CPRS, the genus Eremotherium Spillmann, 1948, previously recorded from other areas of Rio Grande do Sul (Toledo, 1986; Oliveira et al.,

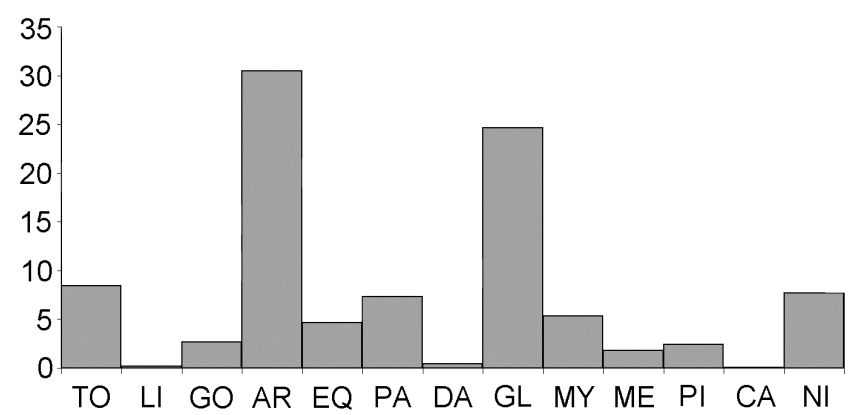

Figure 5. Relative percentages of the taxonomic groups. Abbreviations: TO, Toxodontidae; LI, Litopterna; GO, Gomphotheriidae; AR, Artiodactyla EQ, Equidae; PA, Pampatheriidae; DA, Dasypodidae; GL, Glyptodontidae; MY, Mylodotidae; ME, Megatheriidae; PI, Pilosa indet.; CA, Carnivora NI, unidentified.
2002), was recently identified in the CPRS from deposits of Chuí Creek (Pereira et al., 2010), so it is possible that this genus may also be present among the remains from the continental shelf.

Among the Toxodontidae, the only genus recognized for Rio Grande do Sul is Toxodon Owen, 1838, although a Toxodontidae indet. was recognized the continental shelf by a distal portion of a femur (Paula Couto, 1944; Cunha, 1959) and Oliveira (1992) mentioned the presence of the genus Trigodon Ameghino, 1887 on the basis a fragmentary tooth from the continental shelf. Toxodon was identified in the present analysis by 189 teeth, 15 long bones, 3 skull fragments and 1 astragalus (Figure 7A). Litopterns are rare in the fossil deposits of Rio Grande do Sul (Scherer et al., 2009). The macraucheniid litopterns are represented by two fragmentary teeth and a cervical vertebra of Macrauchenia Owen, 1838 (Figure 7B), while protherotheriids are represented by a single astragalus, attributed to Neolicaphrium Frenguelli, 1921 (Figure 7C).

The Gomphotheriids found in the CPRS are represented by the genus Stegomastodon Pohlig, 1912 according to Marcon (2007). Fossils of this taxon are mostly teeth (62 specimens), but two fragments of dentaries and one tibia were also identified. The teeth include both molar and incisors, mostly fragmented (Figures 7D, E). The most common equid remains are teeth (Figure 7F), although two metatarsals were also identified in the collection. A detailed revision of this material is needed, because the abrasion and fragmentary condition of most of the teeth make it difficult to assign them to a specific genus. However, the identified specimens belong to Equus Linnaeus, 1758 and Hippidion Owen, 1869, previously identified among the material from the continental shelf(Cunha, 1959) and from Chuí Creek (Pereira et al., 2010). The only carnivore specimen in the collection is a left astragalus of Smilodon Lund, 1842 (Lopes \& Buchmann, 2010).
A
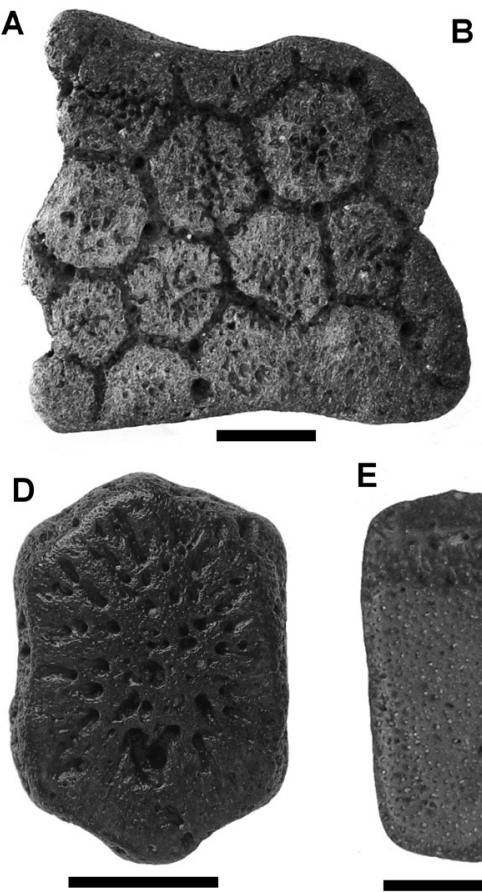

B

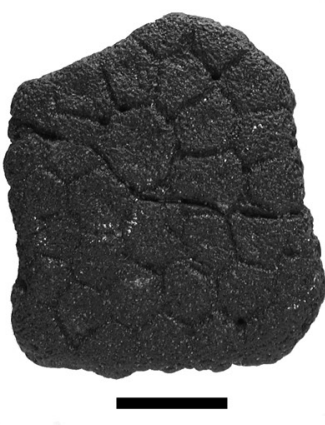

E

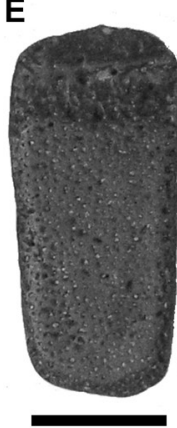

F
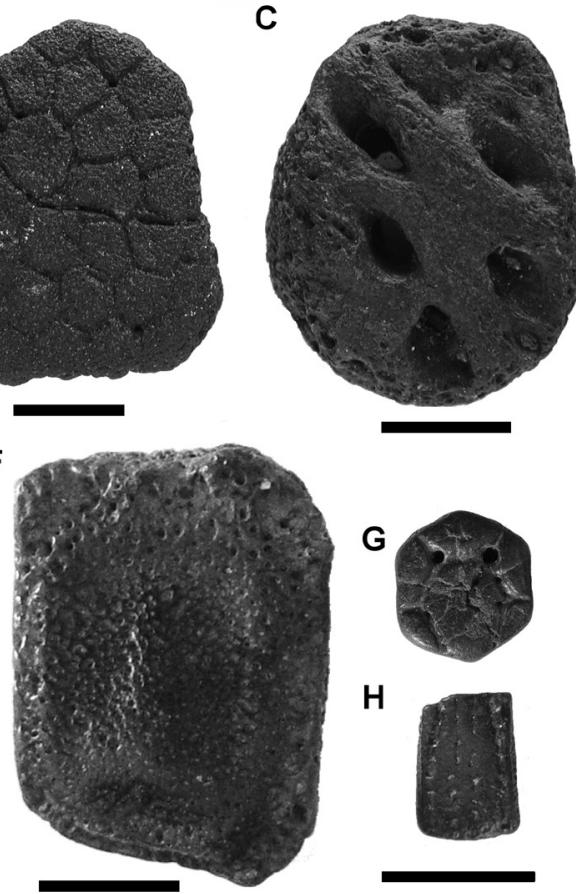

G

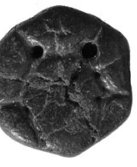

$\mathrm{H}$

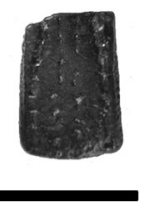

Figure 6. Osteoderms of cingulates. A, LGP-P0256, Glyptodon; B, LGP-P0099, Panochthus; C, LGP-P0098, Doedicurus; D, LGP-P0255, Neuryurus E, LGP-N0207, Pampatherium; F, LGP-N0019, Holmesina; G, LGP-P0211, Pachyarmatherium; H, cf. LGP-N0060, Propraopus. Scale bars = 20 mm. 


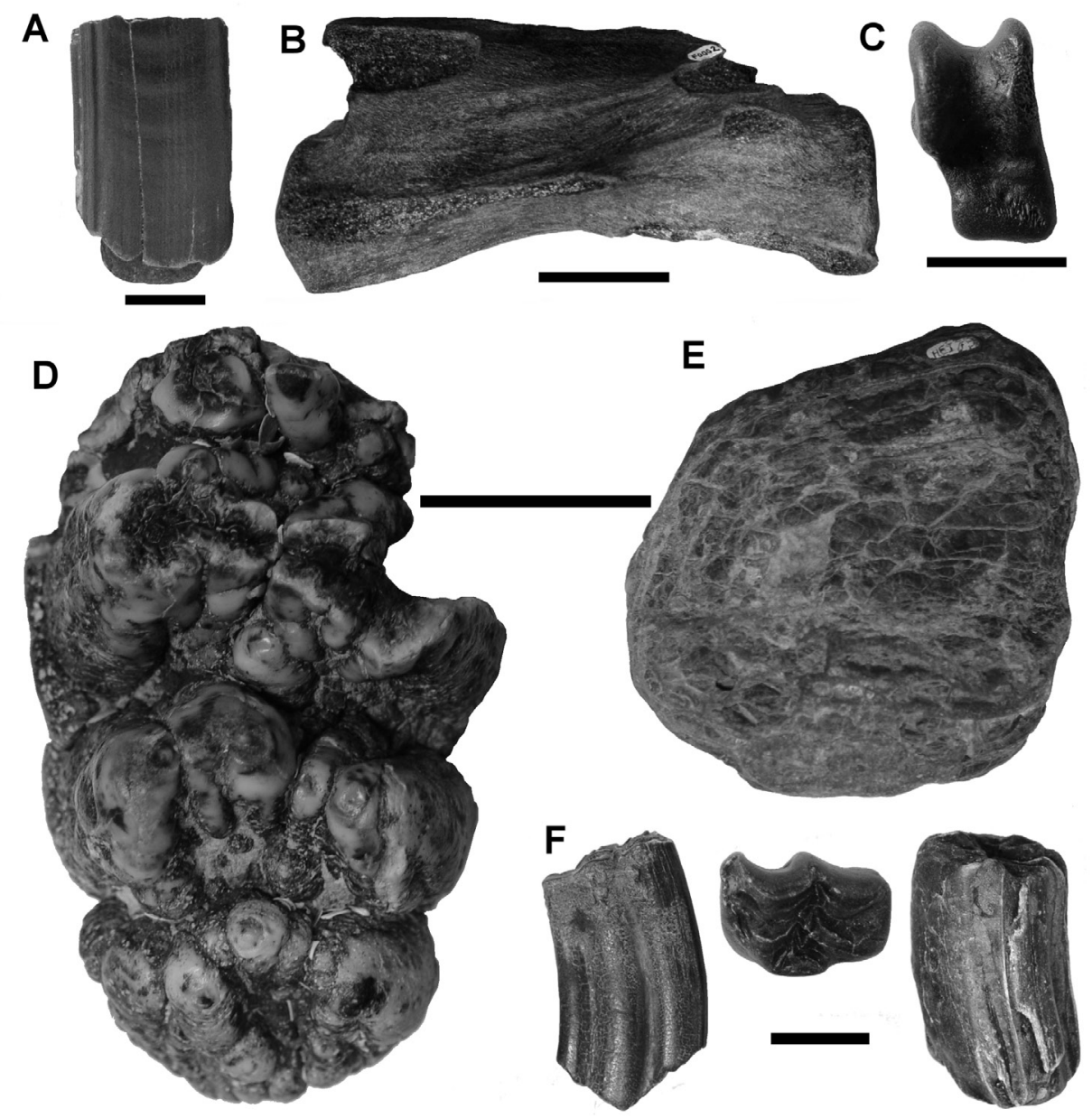

Figure 7. A, LGP-E0126, lower incisor of Toxodon; B, LGP-F0001, cervical vertebra of Macrauchenia; C, LGP-F0004, astragalus of Neolicaphrium; D, LGP-G0044, molar of Stegomastodon; E, LGP-G0051, fragment of an incisor of Stegomastodon; F, LGP-K0009, 0016 and 0017, equid teeth. Scale bars: $A, C, F=20 \mathrm{~mm} ; B, D, E=50 \mathrm{~mm}$.
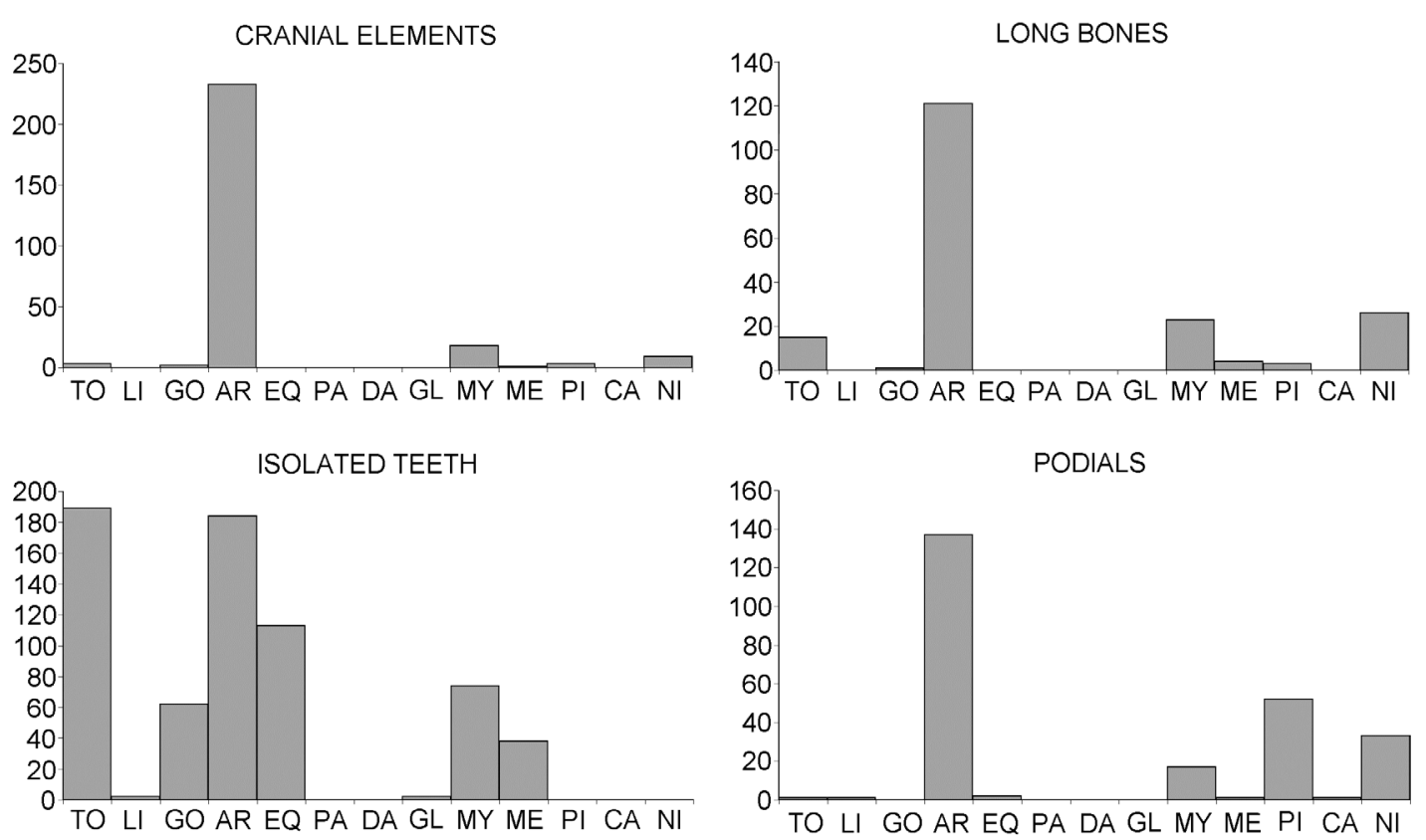

Figure 8. Relative proportions (in absolute numbers) of the different skeletal elements relative to the taxonomic groups. Abbreviations: TO, Toxodontidae; LI, Litopterna; GO, Gomphotheriidae; AR, Artiodactyla; EQ, Equidae; PA, Pampatheriidae; DA, Dasypodidae; GL, Glyptodontidae; MY, Mylodotidae; ME, Megatheriidae; PI, Pilosa indet.; CA, Carnivora; NI, unidentified. 


\section{DISCUSSION}

The analysis of the fossil specimens revealed important variations in the relative proportions among the different mammalian taxonomic groups and respective skeletal elements (Figure 8). Considering that the fossil assemblage from the continental shelf contains remains that encompass a time span of some 700 ky BP (Lopes et al., 2010), reworked and mixed together by the late Pleistocene-early Holocene sea-level oscillations, such variations cannot be attributed only to intrinsic aspects of the paleocommunities. The abundance of glyptodontids among the specimens is a combination of the large number of osteoderms (up to 2000) in the carapace of an individual, plus the small size and compact shape of the osteoderms, which cause them to be easily transported by waves and currents. Among the glyptodontid specimens, however, the predominance of Glyptodon over other genera probably reflects the original diversity pattern among these taxa. Given the similar shape and dimensions of the carapace osteoderms found in these taxa, which results in similar preservation and transport potentials, one should expect to find similar proportions among these genera; however, the marked differences suggest a greater relative abundance of Glyptodon over the other genera in the paleoecosystems of the CPRS. A similar pattern is found among glyptodontid remains from Chuí Creek, which seem to represent a shorter time interval.

Pilose xenarthrans also present differences in relative abundance, with megatheriids less abundant that mylodontids. Among the latter, the mylodontines, represented by Glossotherium, Lestodon and Mylodon are more abundant than scelidotheriines, represented solely by Catonyx according to Lopes \& Pereira (2010). Gaudin (2004) stated that the low representativity of scelidotheriines in Pleistocene fossil assemblages is a product of the low taxonomic diversity of this group.

The record of carnivores is also very scarce, possibly reflecting the low specific richness of this group in South America (Prevosti \& Vizcaíno, 2006). Ecological factors may also be responsible for the low representativity of large-bodied taxa such as Tapirus and Macrauchenia. The abundance of large mammals that presumably inhabited open grassland environments such as ground sloths, mastodonts and glyptodonts (Oliveira, 1999) indicates that the Pleistocene environments of the CPRS were mostly open environments, which would not be suitable for the forest-dwelling Tapirus. Although its remains can be found from Bolivia to Chile (Scherer et al., 2009), it is not clear why Macrauchenia is so scarce in the coastal area of Rio Grande do Sul. Given that this taxon had low-crowned teeth, it is possible that it could feed only on trees and shrubs with soft leaves, instead of the abrasive grasses found in grassland environments. A detailed review on the teeth and postcranial specimens of artiodactyls from the CPRS is necessary in order to evaluate the relative proportion between camelids and cervids.

Other factors to be considered regarding the representativity of the fossils involve taphonomy, mostly the selection by transport and mechanical destruction of the fossils by waves. The fossils are preserved in biodetrital accumulations on the continental shelf until their removal and transportation to the beach by storm waves (Buchmann, 2002; Lopes \& Buchmann, 2010). This process seems to be the main one responsible for the low proportion of large cranial and postcranial remains of large-bodied taxa such as sloths, toxodontids and gomphotheriids. While smaller, more compact remains of small-bodied taxa are easily transported by waves under normal conditions, the larger elements can be transported only by high energy waves, which occur only during extreme storms (Calliari et al., 1998; Lopes et al., 2006). Thus, these large remains rarely come to the beach, but once deposited there, would be removed only by a similar storm, so their residence time on the beach is longer than that of a small fossil continuously moved by normal wave regimes.

Given that the selective transportation results in relatively few large skeletal elements of large-bodied taxa being deposited on the beach, one could expect to find a relatively larger proportion of fossils of smaller-bodied taxa. However, the continuous transportation and reworking in the surf zone by wave action even under normal meteorological conditions results in a higher degree of abrasion, fragmentation and finally destruction of these remains. Even more massive skeletal remains are mostly fragmented and abraded; smaller and more compact-shaped elements are complete but most exhibit a high degree of abrasion due to their higher transportation potential (Lopes et al., 2008). This process explains the abundance of podials of artiodactyls. The abundance of osteoderms of glyptodonts and pampatheriids is a combination of the large proportion of these elements from a single individual and the higher transportability of these elements. The osteoderms of smaller cingulates, such as dasypodids, are more prone to mechanical destruction and abrasion in comparison to osteoderms of glyptodonts and pampatheriids, thus are less abundant.

The higher mechanical resistance of teeth, even those of the xenarthrans that do not bear enamel, contributes to the large proportion of such remains. The abrasion and destruction of most of the fossils is not just a product of present day marine dynamics, but can also be attributed to past sea-level transgressions. Dillenburg (1994) demonstrated that a marine transgression could erode the upper $10 \mathrm{~m}$ of the continental shelf, which would also affect the fossil remains preserved in this area. Past fluvial dynamics could also promote mechanical alteration on these fossils; studies have shown that during sea-level low stands several fluvial channels existed on the exposed portions of the shelf (Weschenfelder et al., 2008; Silva, 2009), thus these rivers could also have transported and destroyed the fossil remains.

The fossil assemblage of the continental shelf represents a time interval that encompasses at least the last $700 \mathrm{ky}$ BP, which was marked by glacioeustatic oscillations. These oscillations reworked and mixed together remains of distinct ages, creating a large parautochthonous assemblage that represents a large time-averaging interval (Lopes et al., 2010). This mixing is responsible for the co-occurrence of non-analogous taxa (sensu Lundelius, 1989), such as organisms that inhabit open, semiarid environments (Dolichotinae, Reithrodon), together with others that indicate forested (Tapirus) and permanently humid (Myocastor, Hydrochoerus) environments. Alternatively, this mixing could be related to the existence in the Pleistocene of environmental conditions not found in modern ecosystems. A similar pattern is observed in fossil assemblages from continental deposits of the Sopas Formation of Uruguay (Ubilla, 2004) and Chuí Creek, although in the latter the mixing could be in fact the result of time-averaging and erosive processes (Lopes, in press).

\section{CONCLUSIONS}

Although the fossil assemblage from the southern Brazilian continental shelf does not represent a single paleocommunity or paleoecosystem, and encompasses remains of different ages, 
the analysis of the skeletal remains revealed that the taxonomic representativity of this assemblage seems to be influenced by a combination of ecological and taphonomic factors. The relative abundance among glyptodontid taxa from this assemblage probably reflects the original taxonomic abundance within this group, with Glyptodon being more diverse and abundant than other glyptodontids. The low ecological diversity explains the scarcity of fossils of carnivores and scelidotheriine sloths. The relative absence of other taxa such as Macrauchenia and Tapirus seems to be related to ecological factors, given that remains of these large-bodied taxa would not be as much affected by taphonomic factors as the small-bodied taxa. This question could be resolved with detailed paleoecological studies and comparison with other geographically and temporally close fossil assemblages.

Taphonomic factors affect the relative proportions of taxa by selective transportation and destruction of the smaller and/or compact-shaped remains. Once removed from the deposits on the shelf, these remains are continuously moved and transported by waves that promote their abrasion and destruction; this process would be a major reason for the relative absence of small organisms such as rodents and proterotheriids. Larger elements, on the other hand, are removed and transported to the beach only on rare occasions when extreme storm waves affect the deposits.

The high proportion of osteoderms of glyptodontids and pampatheriids results from a combination of the large number of these elements on a single individual, plus their higher transportation potential due to their small size and compact shape. The lower proportion of the smaller osteoderms of dasypodids, however, is likely to be a result of mechanical fragmentation and abrasion.

The results presented here are partially hampered by the abrasion and fragmentation of most of the specimens, and also by the lack of a detailed revision of certain groups (e.g. Mylodontidae, Equidae). A careful taxonomic analysis shall improve the taxonomic resolution of the material and improve the estimates of diversity of those groups.

Although it cannot be considered as representing a paleocommunity or paleoenvironment, given the large timeaveraging of the remains, further research on continental fossil localities of more restricted age should provide additional information regarding the Pleistocene mammalian communities and a means for paleoecological comparisons with the assemblage from the continental shelf. This study also reinforces the importance of evaluating the taphonomic processes that affect fossil assemblages when using fossil remains for reconstructing paleoenvironments and paleocommunities.

\section{ACKNOWLEDGEMENTS}

The authors express their gratitude to L. Rota (Santa Vitória do Palmar) for the donation of fossil specimens. Part of this study was possible by financial support by CNPq (Doctorship grant for the co-author).

\section{REFERENCES}

Ameghino, F. 1891. Correspondência entre El Dr. Florentino Ameghino y El Dr. Herman Von Ihering. In: T.J. Torcelli (ed.), Obras Completas y Correspondencia Cientifica, Taller de Impresiones Oficiales, La Plata, 12:131-134.
Bostelmann, E.; Rinderknecht, A. \& Pereira, J.C. 2008. Primeros registros de Glyptatelinae cuaternários (Mammalia, Xenarthra), para el Cono Sur de Sudamérica. In: CONGRESO LATINOAMERICANO DE PALEONTOLOGÍA DE VERTEBRADOS, 3, 2008. Libro de Resúmenes, Neuquén, p. 29.

Buchmann, F.S.C. 1994. Distribuição dos fósseis pleistocênicos na zona costeira e plataforma continental interna no Rio Grande do Sul. Acta Geologica Leopoldensia, 17:355-364.

Buchmann, F.S.C. 2002. Bioclastos de organismos terrestres e marinhos na praia e plataforma interna do Rio Grande o Sul: natureza, distribuição, origem e significado geológico. Programa de Pós-Graduação em Geociências, Universidade Federal do Rio Grande do Sul, Ph.D. thesis, $108 \mathrm{p}$.

Buchmann, F.S.C. \& Rincón Filho, G. 1997. Fósseis de vertebrados marinhos do Pleistoceno Superior na porção sul da planície costeira do Rio Grande do Sul, Brasil. Notas Técnicas, 10:7-16.

Calliari, L.J.; Tozzi, H.A.M. \& Klein, A.H.F. 1998. Beach morphology and coastline erosion associated with storm surges in Southern Brazil - Rio Grande to Chuí, RS. Anais da Academia Brasileira de Ciências, 70:231-247.

Cione, A.L.; Tonni, E.P. \& Dondas, A. 2005. A mastodont (Mammalia, Gomphotheriidae) from the Argentinean continental shelf. Neues Jahrbüch für Geologie und Paläontologie, Monashefte, 10:614-630.

Cione, A.L.; Tonni, E.P. \& Soibelzon, L. 2003. The Broken Zig-Zag: Late Cenozoic large mammal and tortoise extinction in South America. Revista do Museo Argentino de Ciências Naturales, 5:1-19.

Corrêa, I.C.S.; Martins, L.R.S.; Ketzer, J.M.M.; Elias, A.R.D. \& Martins, R. 1996. Evolução sedimentológica e paleogeográfica da plataforma continental sudeste e sul do Brasil. Notas Técnicas, 9:51-61.

Cunha, F.L.S. 1959. Mamíferos fósseis do Pleistoceno do Rio Grande do Sul. I - Ungulados. Boletim do Departamento Nacional da Produção Mineral, Divisão de Geologia e Mineralogia, 202:1-47.

Cunha, F.L.S. 1982. Novos registros de baleias fósseis (Balaenopteridae e Balaenidae) no Pleistoceno de Santa Vitória do Palmar, RS. Anais da Academia Brasileira de Ciências, 54:264.

Dillenburg, S.R., 1994. O potencial de preservação dos registros sedimentares do Sistema Deposicional Laguna/Barreira IV na costa do Rio Grande do Sul. Notas Técnicas, 9:1-11.

Fariña, R.; Vizcaíno, S.F. \& Bargo, M.S. 1998. Body mass estimations in Lujanian (Late Pleistocene - Early Holocene of South America) mammal megafauna. Mastozoología Neotropical, 5:87-108.

Figueiredo Jr., A.G. 1975. Geologia dos depósitos calcários biodetríticos da plataforma continental do Rio Grande do Sul. Programa de PósGraduação em Geociências, Universidade Federal do Rio Grande do Sul, M.Sc. thesis, $72 \mathrm{p}$.

Gaudin, T.J. 2004. Phylogenetic relationships among sloths (Mammalia, Xenarthra, Tardigrada): the craniodental evidence. Zoological Journal of the Linnean Society, 140:255-305.

Hsiou, A.S. 2009. O registro fóssil de répteis e aves no Pleistoceno final do Estado do Rio Grande do Sul, Brasil. In: Ribeiro, A.M.; Bauermann, S.G. \& Scherer, C.S. (orgs.) Quaternário do Rio Grande do Sul: integrando conhecimentos, Monografias da Sociedade Brasileira de Paleontologia, p. 143-154.

Hsiou, A.S. \& Fortier, D.C. 2007. Primeiro registro de Caiman (Crocodylia, Alligatoridae) para o Pleistoceno do Estado do Rio Grande do Sul, Brasil. Gaea, 3:37-44.

Kowsmann, R.O. \& Costa, M.P.A. 1974. Paleolinhas de costa na plataforma continental das regiões sul e norte brasileira. Revista Brasileira de Geociencias, 4:215-222.

Kraglievich, L. 1934. Contribución al conocimiento de "Mylodon darwini" Owen y espécies afines. Revista del Museo de La Plata, 35:255-292.

Lopes, R.P. 2011. Fossil sand dollars (Echinoidea: Clypeasteroida) from the southern Brazilian coast. Revista Brasileira de Paleontologia, 14:201-214. doi:10.4072/rbp.2011.3.01

Lopes, R.P. in press. Biostratigraphy of the Pleistocene fossiliferous deposits of southern Brazilian coastal area. Journal of Mammalian Evolution. doi: 10.1007/s10914-011-9173-y 
Lopes, R.P. \& Buchmann, F.S.C. 2008. Comparação tafonômica entre duas concentrações fossilíferas (shell beds) da Planície Costeira do Rio Grande do Sul, Brasil. Gaea, 4:65-77.

Lopes, R.P. \& Buchmann, F.S.C. 2010. Pleistocene mammals from the southern Brazilian continental shelf. Journal of South American Earth Sciences, 31:17-27. doi:10.1016/j.jsames.2010.11.003

Lopes, R.P.; Buchmann, F.S.C. \& Caron, F. 2006. Primeiro registro de fósseis de aves marinhas na Planície Costeira do Rio Grande do Sul, Brasil. Revista Brasileira de Geociências, 36:648-650.

Lopes, R.P.; Buchmann, F.S.C. \& Caron, F. 2008. Taphonomic analysis on fossils of Pleistocene mammals from deposits submerged along Southern Rio Grande do Sul coastal plain, Brazil. Arquivos do Museu Nacional, 66:213-229.

Lopes, R.P.; Oliveira, L.C.; Figueiredo, A.M.G.; Kinoshita, A.; Baffa, O. \& Buchmann, F.S.C. 2010. ESR dating of Pleistocene mammal teeth and its implications for the biostratigraphy and geological evolution of the coastal plain, Rio Grande do Sul, southern Brazil. Quaternary International, 212:213-222. doi:10.1016/j.quaint.2009.09.018

Lopes, R.P. \& Pereira, J.C. 2010. Fossils of Scelidotheriinae Ameghino, 1904 (Xenarthra, Pilosa) in the Pleistocene deposits of Rio Grande do Sul, Brazil. Gaea, 6:44-52.

Lundelius Jr., E.L. 1989. The implications of disharmonious assemblages for Pleistocene extinctions. Journal of Archaeological Science, 16:407-417.

Marcon, G.T.G. 2007. Contribuição ao estudo dos Proboscidea (Mammalia, Gomphotheriidae) do Quaternário do Estado do Rio Grande do Sul, Brasil. Programa de Pós-Graduação em Geociências, Universidade Federal do Rio Grande do Sul, M.Sc. thesis, 113 p.

Martins, L.R.S.; Urien, C.M.; Corrêa, I.C.S. \& Martins, I.R. 1996. Late Quaternary processes along the Rio Grande do Sul continental shelf (southern Brazil). Notas Técnicas, 9:62-68.

McKenna, M.C. \& Bell, S.K. 1997. Classification of mammals above the species level. New York, Columbia University Press, $631 \mathrm{p}$.

Mol, D.; Post, K.; Reumer, J.W.F.; van der Plicht, J.; de Vos, J.; van Geel, B.; van Reenen, G.; Pals, J.P. \& Glimmerveen, J. 2006. The Eurogeul - first report of the palaeontological, palynological and archaeological investigations of this part of the North Sea. Quaternary International, 142-143:178-185. doi: 10.1016/j.quaint.2005.03.015

Oliveira, E.V. 1992. Mamíferos fósseis do Pleistoceno Superior - Holoceno do Rio Grande do Sul, e seu significado paleoecológico. Programa de Pós-Graduação em Geociências, Universidade Federal do Rio Grande do Sul, M.Sc. thesis, $118 \mathrm{p}$.

Oliveira, E.V. 1996. Mamíferos Xenarthra (Edentata) do Quaternário do Estado do Rio Grande do Sul, Brasil. Ameghiniana, 33:65-75.

Oliveira, E.V. 1999. Quaternary vertebrates and climates of southern Brazil. In: J. Rabassa \& M. Saleme (eds.) Quaternary of South America and Antarctica Peninsula, A.A. Balkema, Rotterdam, 12:61-73.

Oliveira, E.V. \& Drehmer, C.J., 1997. Sobre alguns restos de PinnipediaOtariidae (Mammalia, Carnivora) do Quaternário do Estado do Rio Grande do Sul, Brasil. Revista da Universidade Guarulhos, Geociências, 2:19-22.

Oliveira, E.V.; Dutra, T.L. \& Zeltzer, F. 2002. Megaterídeos (Mammalia, Xenarthra) do Quaternário de Caçapava do Sul, Rio Grande do Sul, com considerações sobre a flora associada. Geologia Colombiana, 27:77-86.

Paula Couto, 1944. Sobre a presença dos gêneros Hippidion e Toxodon Owen no Pleistoceno do Rio Grande do Sul. Boletim do Museu Nacional (Nova Série), 2:1-12.

Paula Couto, C. \& Cunha, F.L.S. 1965. Nota preliminar sobre o reconhecimento geo-paleontológico do Rio Grande do Sul. Boletim do Departamento Nacional da Produção Mineral, Divisão de Geologia e Mineralogia, 40:49-50.

Pereira, J.C.; Kerber, L. \& Lopes, R.P. 2010. Novas ocorrências de mamíferos nos depósitos fossilíferos do Arroio Chuí (Pleistoceno Tardio), Rio Grande do Sul. Paleontologia em Destaque, Boletim Informativo da Sociedade Brasileira de Paleontologia, p. 48-49.

Porpino, K.O.; Fernicola, J.C. \& Bergqvist, L.P. 2009. A new cingulate (Mammalia: Xenarthra), Pachyarmatherium brasiliense sp. nov., from the Late Pleistocene of Northeastern Brazil. Journal of Vertebrate Paleontology, 29:881-893. doi:10.1671/039.029.0305
Prevosti, F.J. \& Vizcaíno, S.F. 2006. Paleoecology of the large carnivore guild from the Late Pleistocene of Argentina. Acta Palaeontologica Polonica, 51:407-422.

Ribeiro, A.M.; Drehmer, C.J.; Buchmann, F.S.C. \& Simões-Lopes, P.C., 1998. Pleistocene skull remains of Pontoporia blainvillei (Cetacea, Pontoporidae) from the coastal plain of Rio Grande do Sul State, Brazil and the relationship of pontoporids. Revista da Universidade de Guarulhos, Geociências, 3:71-77.

Ribeiro, A.M.; Scillato-Yané, G.J.; Carlini, A.A.; Scherer, C.S. \& Lopes, R.P. 2008. Sobre a provável presença de Glyptatelinae (Cingulata, Xenarthra) para o Pleistoceno da Planície Costeira do Rio Grande do Sul, Brasil. In: CONGRESO LATINOAMERICANO DE PALEONTOLOGÍA DE VERTEBRADOS, 3, 2008. Libro de Resúmenes, Neuquén, p. 213.

Richter, M. 1987. Osteicthyes e elasmobranchii (Pisces) da Bacia de Pelotas, Quaternário do R.G.S., Brasil. Paula-Coutiana, 1:17-37.

Rinderknecht, A. 2006. Vertebrados fósiles de la costa uruguaya. In: R. Menara, L. Rodríguez-Gallego, F. Scarabino \& D. Conde (eds.) Bases para la conservación y el manejo em la costa uruguaya. Sociedad Uruguaya para la Conservación de la Naturaleza, p. 1-7.

Rodrigues, P.H. \& Ferigolo, J. 2004. Roedores pleistocênicos da planície costeira do Estado do Rio Grande do Sul, Brasil. Revista Brasileira de Paleontologia, 7:231-238.

Rodrigues, P.H.; Prevosti, F.J.; Ferigolo, J. \& Ribeiro, A.M. 2004. Novos materiais de Carnivora para o Pleistoceno do Estado do Rio Grande do Sul, Brasil. Revista Brasileira de Paleontologia, 7:77-86.

Scherer, C.S. 2005. Estudo dos Camelidae (Mammalia, Artiodactyla) do Quaternário do Estado do Rio Grande do Sul, Brasil. Programa de Pós-Graduação em Geociências, Universidade Federal do Rio Grande do Sul, M.Sc. thesis, 176 p.

Scherer, C.S.; Pitana, V.G. \& Ribeiro, A.M. 2009. Proterotheriidae and Macraucheniidae (Litopterna, Mammalia) from the Pleistocene of Rio Grande do Sul State, Brazil. Revista Brasileira de Paleontologia, 12:231-246. doi: 10.4072/rbp.2009.3.06

Silva, J.L.B. 2009. Identificação do sistema de paleodrenagem na margem continental sul brasileira adjacente à Lagoa Mirim no Terciário Superior por sísmica de reflexão. Programa de Pós-Graduação em Geociências, Universidade Federal do Rio Grande do Sul, Ph.D. thesis, $215 \mathrm{p}$.

Toledo, P.M. 1986. Descrição do sincrânio de Eremotherium laurillardi Lund, 1842, taxonomia e paleobiogeografia. Programa de PósGraduação em Geociências, Universidade Federal do Rio Grande do Sul, M.Sc. thesis, 127 p.

Tomazelli, L.J.; Dillenburg, S.R. \& Villwock, J.A. 2000. Late Quaternary geological history of Rio Grande do Sul coastal plain, southern Brazil. Revista Brasileira de Geociências, 30:474-476.

Tonni, E.P. \& Cione, A.L. 1999. Pleistocene continental vertebrates from the present marine shelf of Argentina. Current Research in the Pleistocene, 16:134-136.

Ubilla, M. 2004. Mammalian biostratigraphy of Pleistocene deposits in northern Uruguay, South America. Proceedings of the Geologists Association, 115:347-357. doi: 10.1016/S0016-7878(04)80014-2

Van Kolfschoten, T. \& Laban, C. 1995. Pleistocene terrestrial mammal faunas from the North Sea. Mededefingen flijks geologische Dienst, 52:135-151.

Villwock, J.A. \& Tomazelli, L.J. 1995. Geologia Costeira do Rio Grande do Sul. Notas Técnicas, 8:1-45.

Weschenfelder, J.; Corrêa, I.C.S.; Toldo Jr., E.E. \& Baitelli, R. 2008. Paleocanais como indicativo de eventos regressivos quaternários do nível do mar no sul do Brasil. Revista Brasileira de Geofísica, 26:367-375. doi: 10.1590/S0102-261X2008000300009

Whitmore Jr., F.C.; Emery, K.O.; Cooke, H.B.S. \& Swift, D.J.P. 1967. Elephant teeth from the Atlantic continental shelf. Science, 156:1477-1481.

Zurita, A.E.; Soibelzon, E. \& Carlini, A.A. 2006. Neuryurus (Xenarthra, Glyptodontidae) in the Lujanian (late Pleistocene - early Holocene) of the Pampean Region. Neues Jahrbüch für Geologie und Paläontologie, 2:78-88.

Received in March, 2011; accepted in February, 2012. 